\title{
Bat flies (Diptera: Streblidae) ectoparasites of bats at an Atlantic Rainforest site in northeastern Brazil
}

\author{
Fábio Angelo Melo Soares ${ }^{1,7}$, Gustavo Graciolli ${ }^{2,6}$, Daniel Máximo Corrêa Alcântara', \\ Carlos Eduardo Borges Pinto Ribeiro ${ }^{3}$, Gustavo Corrêa Valença ${ }^{4}$ \& Stephen Francis Ferrari ${ }^{5}$ \\ ${ }^{1}$ Programa de Pós-graduação em Ecologia e Conservação, Universidade Federal de Sergipe - UFS, \\ Av. Marechal Rondon, s/n, Jardim Rosa Elze, CEP 49100-000, São Cristóvão, SE, Brasil \\ ${ }^{2}$ Departamento de Biologia, Centro de Ciências Biológicas e Saúde-CCBS, Universidade Federal do \\ Mato Grosso do Sul-UFMS, CP 549, CEP 79070-900, Campo Grande, MS, Brasil \\ ${ }^{3}$ Faculdade Frassinetti do Recife - Fafire, Av. Conde da Boa Vista, 921, Boa Vista, \\ CEP 50060-002, Recife, PE, Brasil \\ ${ }^{4}$ Programa de Pós-graduação em Biologia Animal da Universidade Federal de Pernambuco - UFPE, \\ Av. Moraes Rego, 1235, Cidade Universitária, CEP 50670-901, Recife, PE, Brasil \\ ${ }^{5}$ Departamento de Biologia, Universidade Federal de Sergipe - UFS, Av. Marechal Rondon, s/n, \\ Jardim Rosa Elze, CEP 49100-000, São Cristóvão, SE, Brasil \\ ${ }^{6}$ Bolsista Produtividade do CNPq (proc. no. \# 304459/2008-9). \\ ${ }^{7}$ Corresponding author: Fábio Angelo Melo Soares, e-mail: fabiosoares9@gmail.com
}

SOARES, F.A.M., GRACIOLLI, G., ALCÂNTARA, D.M.C., RIBEIRO, C.E.B.P., VALENÇA, G.C. \& FERRARI, S.F. Bat flies (Diptera: Streblidae) ectoparasites of bats at an Atlantic Rainforest site in northeastern Brazil. Biota Neotrop. (13)2: http://www.biotaneotropica.org.br/v13n2/en/abstract?inventory+bn03513022013.

Abstract: Bat flies were surveyed between March, 2007 and February, 2008, in the Carnijó Private Natural Heritage Reserve $\left(08^{\circ} 07^{\prime} \mathrm{S}\right.$ and $\left.35^{\circ} 05^{\prime} \mathrm{W}\right)$, an area of Atlantic Rainforest in the municipality of Moreno, in the Brazilian state of Pernambuco. Bats were captured biweekly using mist nets set during six hours each night. The ectoparasites were collected with tweezers and/or a brush wet in ethanol and stored in $70 \%$ ethanol. The specimens are deposited in the zoological reference collection of the Federal University of Mato Grosso do Sul. Sixteen species of streblid bat flies were collected from 10 bat species of the family Phyllostomidae. Thirteen of the these streblid species were recorded for the first time in Pernambuco.

Keywords: Chiroptera, ectoparasites, Atlantic Rainforest, Phyllostomidae, Streblidae.

SOARES, F.A.M., GRACIOLLI, G., ALCÂNTARA, D.M.C., RIBEIRO, C.E.B.P., VALENÇA, G.C. \& FERRARI, S.F. Moscas (Diptera: Streblidae) ectoparasitas de morcegos em uma área de Mata Atlântica do Nordeste do Brasil. Biota Neotrop. (13)2: http://www.biotaneotropica.org.br/v13n2/pt/abstract?inventory+bn03513022013.

Resumo: O presente estudo ocorreu entre Março de 2007 e Fevereiro de 2008 na Reserva Particular do Patrimônio Natural Carnijó (08 $07^{\circ}$ S e 35 $5^{\circ}$ 05' W), área de Mata Atlântica, localizada no município de Moreno, Pernambuco, Brasil. Os morcegos foram capturados quinzenalmente com redes de neblina por um intervalo de seis horas por noite. A coleta dos ectoparasitos foi realizada com auxílio de pinça e/ou um pincel umedecido com álcool, sendo mantidos em etanol 70\%. Os espécimens estão depositados na Coleção Zoológica de Referência da Fundação Universidade Federal de Mato Grosso do Sul. Dezesseis espécies de moscas estreblídeas foram capturadas sobre 10 espécies de morcegos da família Phyllostomidae. Treze espécies de estreblídeas encontradas no presente trabalho foram registradas pela primeira vez para o estado de Pernambuco.

Palavras-chave: Chiroptera, ectoparasitos, Mata Atlântica, Phyllostomidae, Streblidae. 


\section{Introduction}

The bat flies (Diptera, Streblidae) are ectoparasites hematophagous exclusive of bats, with a worldwide distribution (Wenzel et al. 1966). A total of 237 streblid species have been described to date, distributed in 33 genera and five subfamilies. Two of these subfamilies, the Brachytarsininae (four genera and 60 species) and the Ascodipterinae (three genera and 21 species) are restricted to the Old World, while the Nycterophiliinae (two genera and six species), Trichobiinae (20 genera and 115 species), and Streblinae (four genera and 35 species) are endemic to the New World (Dick \& Graciolli 2008).

In the Americas, streblids mainly parasitize bats of the Phyllostomidae family (Prevedello et al. 2005), although relatively few data are available on the distribution of the different taxa or the host-parasite relationship, despite considerable advances in recent years (e.g. Graciolli et al. 2008, Graciolli \& Rui, 2001). A total of 70 streblid species have been recorded in Brazil, although the vast majority of the data are from the southern and central regions of the country (Graciolli \& Carvalho 2001, Aguiar et al. 2006, Graciolli et al. 2008, Dias et al. 2009), whereas few faunistic surveys have been conducted in the Northeast, where only 26 streblid species have been reported. Most of these species (22) were recorded during a long-term survey in Maranhão state (Dias et al. 2009), while Rios et al. (2008) registered two other species in Bahia state.

In the specific case the state of Pernambuco, the only published data available are those of Guimarães (1938), who recorded five species, although the host of only one species was known. While approximately $42 \%(n=67)$ of the bat species found in Brazil are known to occur in Pernambuco, virtually nothing is known of their ectoparasites. The present study provides the first data on the occurrence of streblid ectoparasites on phyllostomid bats captured in a fragment of Atlantic Rainforest in the Brazilian state of Pernambuco.

\section{Material and Methods}

Specimens were collected at the Carnijó Private Natural Heritage Reserve (RPPN Carnijó), located in the municipality of Moreno $\left(08^{\circ}\right.$ $07^{\prime} \mathrm{S}$ and $35^{\circ} 05^{\prime} \mathrm{W}$ ), about $30 \mathrm{~km}$ from Recife, the capital of the Pernambuco state. The reserve covers an area of 25.5 ha of secondary Atlantic Rainforest, in which plant species of the Cecropiaceae, Moraceae, Piperaceae, Cucurbitaceae, and Solanaceae families predominate. The climate is characterized by two distinct seasons, a rainy season, between April and August, and a dry season during the remaining months of the year (Andrade-Lima 1960). The historical mean annual rainfall in the region is $1025 \mathrm{~mm}$.

Samples were collected biweekly between March 2007 and February 2008, comprising a total of 24 nights of collection. The bats were captured in four $12 \mathrm{~m} \times 3 \mathrm{~m}$ mist-nets, which were set along established trails and within natural glades. The individuals were identified in the field using the taxonomic keys of Vizotto \& Taddei (1973), and Gardner 2007), and were then released back into the wild. The nets were set for 6 hours each night and checked at intervals of 20-30 minutes. The fur of the captured bats was inspected by the naked eye or using a hand lens, and the ectoparasites observed were collected with tweezers and/or brushes wet in ethanol. The specimens were stored in vials - one for each host captured on a given night - with $70 \%$ ethanol. All the specimens were deposited in the zoological reference collection of the Federal University of Mato Grosso do Sul in Campo Grande, Brazil.

\section{Results and Discussion}

A total of 331 bats were captured and examined, representing the families Phyllostomidae $(\mathrm{n}=327)$, Mollosidae $(\mathrm{n}=1)$, and Emballonuridae $(\mathrm{n}=3)$. Of these, 99 specimens (all phyllostomids) were parasitized by streblid bat flies. A total of 353 streblid specimens were collected from 10 phyllostomid species (Table 1). Thirteen of the streblid species were recorded for the first time in Pernambuco (Table 2), increasing the number of species known to occur in this state to 19. Comments on the parasites and their hosts are provided below. Aspidoptera falcata Wenzel, 1976

Material examined: 1 female; ex Sturnira lilium (E. Geoffroy 1810).

Table 1. List of bat species (Chiroptera, Phyllostomidae) and their respective ectoparasite species (Diptera: Streblidae) recorded in the RPPN Carnijó in the municipality of Moreno, Pernambuco state, Brazil.

\begin{tabular}{|c|c|c|}
\hline Bat species (total number of specimens collected) & Parasite species & Number of ectoparasites collected \\
\hline Artibeus lituratus $(\mathrm{N}=15)$ & Paratrichobius longicrus & 22 \\
\hline \multirow[t]{3}{*}{ Carollia perspicillata $(\mathrm{N}=220)$} & Trichobius joblingi & 144 \\
\hline & Speiseria ambigua & 47 \\
\hline & Strebla guajiro & 2 \\
\hline Desmodus rotundus $(\mathrm{N}=5)$ & Trichobius parasiticus & 1 \\
\hline Lonchorhina aurita $(\mathrm{N}=1)$ & Strebla altmani & 4 \\
\hline \multirow[t]{3}{*}{ Lophostoma silvicolum $(\mathrm{N}=1)$} & Trichobius affinis & 1 \\
\hline & Mastoptera minuta & 6 \\
\hline & Strebla tonatiae & 2 \\
\hline \multirow[t]{2}{*}{ L. brasiliense $(\mathrm{N}=1)$} & Mastoptera minuta & 15 \\
\hline & Trichobius longipes & 2 \\
\hline \multirow[t]{3}{*}{ Phyllostomus discolor $(\mathrm{N}=13)$} & Trichobius costalimai & 42 \\
\hline & Trichobioides perspicillatus & 4 \\
\hline & Trichobius longipes & 13 \\
\hline \multirow[t]{2}{*}{ Platyrrhinus lineatus $(\mathrm{N}=18)$} & Trichobius sp. (dugesii complex) & 2 \\
\hline & Paratrichobius longicrus & 6 \\
\hline \multirow[t]{2}{*}{ Sturnira lilium $(\mathrm{N}=4)$} & Megistopoda proxima & 7 \\
\hline & Aspidoptera falcata & 1 \\
\hline Trachops cirrhosus $(\mathrm{N}=3)$ & T. dugesioides dugesioides & 32 \\
\hline Total & & 353 \\
\hline
\end{tabular}


Table 2. Streblíd bat flies and their respective host species of bats recorded in the Brazilian state of Pernambuco. Sources: 1 - Guimarães (1938), 2 - present study. ${ }^{\text {a }}$ - New geographical record for Pernambuco state, ${ }^{\mathrm{b}}$ - New host record.

\begin{tabular}{|c|c|c|}
\hline Streblid species & Host & Source \\
\hline 1. Aspidoptera falcata ${ }^{\text {a }}$ & Sturnira lilium & 2 \\
\hline \multirow[t]{2}{*}{ 2. Mastoptera minuta ${ }^{\text {a }}$} & Lophostoma silvicolum & 2 \\
\hline & L. brasiliense & 2 \\
\hline 3. Megistopoda proxima ${ }^{\text {a }}$ & Sturnira lilium & 2 \\
\hline \multirow[t]{2}{*}{ 4. Paratrichobius longicrus ${ }^{\text {a }}$} & Platyrrhinus lineatus & 2 \\
\hline & Artibeus lituratus & 2 \\
\hline 5. Speiseria ambígua ${ }^{\text {a }}$ & Carollia perspicillata & 2 \\
\hline 6. Strebla altmani ${ }^{\text {a }}$ & Lonchorhina aurita & 2 \\
\hline 7. S. guajiro a & Carollia perspicillata & 2 \\
\hline 8. S. tonatiae a & Lophostoma silvicolum & 2 \\
\hline 9. Trichobioides perspicillatus ${ }^{\text {a }}$ & Phyllostomus discolor & 2 \\
\hline 10. Trichobius affinis a & Lophostoma silvicolum $^{\mathrm{b}}$ & 2 \\
\hline 11. Trichobius sp. (dugesii complex) & Platyrrhinus lineatus & 2 \\
\hline \multirow[t]{2}{*}{ 12. T. costalimai } & Indeterminado & 1 \\
\hline & Phyllostomus discolor & 2 \\
\hline 13. T. dugesii & Indeterminado & 1 \\
\hline 14. T. dugesioides dugesioides ${ }^{\text {a }}$ & Trachops cirrhosus & 2 \\
\hline 15. T. joblingi $i^{\text {a }}$ & Carollia perspicillata & 2 \\
\hline 16. T. parasiticus & Indeterminado, Desmodus rotundus & 1,2 \\
\hline 17. T. uniformis & Indeterminado & 1 \\
\hline
\end{tabular}

Comments: New occurrence for the state of Pernambuco. Aspidoptera falcata occurs primarily on S. lilium, and has been recorded in the Brazilian states of Roraima (Graciolli \& Linardi 2002), Pará (Graciolli \& Aguiar 2002), Maranhão (Dias et al. 2009), Distrito Federal (Guerrero 1997, Graciolli \& Aguiar 2002,), Minas Gerais (Whitaker Junior \& Mumford 1997, Komeno \& Linhares 1999, Azevedo \& Linardi 2002), São Paulo (Bertola et al. 2005), Paraná (Graciolli \& Carvalho 2001), and Santa Catarina (Graciolli et al. 2008).

Mastoptera minuta (Costa Lima 1921)

Material examined: 2 males, 4 females; ex Lophostoma silvicolum D’Orbygny 1836. 7 males, 8 females; ex Lophostoma brasiliense Peters 1866.

Comments: New occurrence for the state of Pernambuco. Mastoptera minuta represents a complex of species found on bats of the genera Lophostoma d'Orbygny 1836 and Tonatia Gray, 1827 (Guerrero 1995b).

Megistopoda proxima (Séguy 1926)

Material examined: 4 males, 3 females; ex Sturnira lilium.

Comments: New occurrence for the state of Pernambuco. Megistopoda proxima is a complex of species that parasitizes exclusively bats of the genus Sturnira Gray, 1842 (Wenzel 1976).

Paratrichobius longicrus (Miranda Ribeiro 1907)

Material examined: 4 males, 2 females; ex Platyrrhinus lineatus (E. Geoffroy 1810). 9 males, 13 females; ex Artibeus lituratus (Olfers 1818).

Comments: New occurrence for the state of Pernambuco. Paratrichobius longicrus is considered to be a complex of species (Wenzel et al. 1966). While the specimens collected from A. lituratus were identified as $P$. longicrus, those captured on $P$. lineatus may represent an undescribed species.

Speiseria ambigua Kessel 1925

Material examined: 24 males, 16 females; ex Carollia perspicillata (Linnaeus 1758).

Comments: The type locality of S. ambigua is in Pernambuco (Guerrero 1994). The species ranges from Mexico to southern Brazil
(Guerrero 1994, Graciolli \& Carvalho 2001), and is an exclusive parasite of C. perspicillata (Wenzel 1976, Guerrero 1994).

Strebla altmani Wenzel 1966

Material examined: 2 males, 2 females; ex Lonchorhina aurita Tomes 1863.

Comments: New occurrence for the state of Pernambuco. In Brazil, this species had been recorded previously only in the states of Roraima (Graciolli \& Linardi 2002) and Distrito Federal (Coimbra Junior et al. 1984).

Strebla guajiro (García \& Casal 1965)

Meterial examined: 1 male; ex Carollia perspicillata.

Comments: New occurrence for the state of Pernambuco. Strebla guajiro typically parasitizes bats of the genus Carollia Gray 1838 (Wenzel 1976).

Strebla tonatiae (Kessel 1924)

Material examined: 1 male, 1 female; ex Lophostoma silvicolum. Comments: New occurrence for the state of Pernambuco. First record of $S$. tonatiae parasitizing $L$. silvicolum. In Maranhão state, $S$. tonatiae was recorded on L. brasiliense (Dias et al. 2009), which was so far the typical host of this parasite (Wenzel 1976, Guerrero 1996). Trichobius parasiticus Gervais 1844

Material examined: 1 male; ex Desmodus rotundus (E. Geoffroy 1810).

Comments: Previously recorded in the state of Pernambuco by Guimarães (1938).

Trichobius affinis Wenzel 1976

Material examined: 1 male; ex Lophostoma silvicolum.

Comments: New occurrence for the state of Pernambuco. Recorded in the state of Pará on its type host, Lophostoma brasiliense Graciolli \& Bernard (2002).

Trichobius costalimai Guimarães 1938

Material examined: 24 males, 18 females; ex Phyllostomus discolor Wagner 1843.

Comments: Species described by Guimarães (1938) from a specimen captured in Recife, the capital of Pernambuco state, 
although the host was not reported. According to Wenzel et al. (1966) and Wenzel (1976), T. costalimai is a primary parasite of $P$. discolor.

Trichobius sp. (dugesii complex)

Material examined: 2 males; ex Platyrrhinus lineatus.

Comments: Most species of this complex are morphologically very similar, which impedes reliable identification without adequate reference material (Wenzel 1976).

Trichobius dugesioides dugesioides Wenzel 1966

Material examined: 24 males, 7 females; ex Trachops cirrhosus (Spix 1823).

Comments: New occurrence for the state of Pernambuco. The association between these species was reported in Brazil by Graciolli \& Linardi (2002) in Roraima state.

Trichobius joblingi Wenzel 1966

Material examined: 84 males, 38 females; ex Carollia perspicillata.

Comments: New occurrence for the state of Pernambuco. Trichobius joblingi was the most abundant species in the present study, and it appears to be the most common streblid parasite in the Neotropics (Guerrero 1995a). This parasite is common in Central and South America, where C. perspicillata is also its typical host (Wenzel 1976).

Trichobius longipes (Rudow 1871)

Material examined: 1 male, 1 female; ex Lophostoma brasiliense. 8 males, 5 females; ex Phyllostomus discolor.

Comments: Species previously documented in Pernambuco by Guimarães (1938) as Trichobius mixtus Curran 1935. While $T$. longipes has been captured on L. brasiliense and P. discolor, its primary host is Phyllostomus hastatus Pallas 1767 (Wenzel et al. 1966).

Trichobioides perspicillatus (Pessôa \& Galvão 1937)

Material examined: 2 males, 2 females; ex Phyllostomus discolor.

Comments: New occurrence for the state of Pernambuco. This bat species was the host for $97 \%$ of the $T$. perspicillatus specimens from 30 locations examined by Wenzel (1976), which indicates that it is the primary host for this parasite.

\section{Conclusion}

With the exception of the observation of Trichobius affinis on Lophostoma silvicolum, the host-parasite associations recorded in the present study were expected due to previous reports from other localities. Thirteen streblid species were recorded for the first time in Pernambuco, increasing to 18 the number of species known to occur in this Brazilian state. This number of species is still lower that found in other Brazilian states, such as Paraná (31), Pará (28), São Paulo (25), Maranhão (22), and in Federal District (37), where at least 53, 116, 69, 37 , and 47 species of bats are known to occur, respectively. As at least 67 bat species are known to occur in Pernambuco (45 in the Atlantic Rainforest alone), it seems likely that the relatively reduced streblid species richness recorded in this state is a sampling effect resulting from the relatively small number of studies available. In this case, the number of streblid species occurring in that state will probably grow considerably as new sites, and new environments, such as the Caatinga, scrublands and the coastal mangrove forests, are surveyed.

\section{Acknowledgments}

We thank the Scientific Initiation Nucleus (NUPIC) of the Frassinetti Faculty in Recife for encouragement and financial support, PRNH Carnijó for logistical support and permission for the research, Narciso Leite, Leonardo Carrasco, and Raul Perrelli helped with fieldwork, and Dr. Múcio Banja for his support during the research.

\section{References}

AGUIAR, L.M.S. CAMARGO, W.R. \& PORTELLA, A.S. 2006. Occurrence of white-wing bat, Diaemus youngi (Mammalia, Chiroptera), in the Cerrado of Distrito Federal, Brazil. Rev. Bras. Zool. 23(3):893-896. http://dx.doi.org/10.1590/S0101-81752006000300041

ANDRADE-LIMA, D. 1960. Estudos fitogeográficos de Pernambuco. Arq. Inst. Pesq. Agro. 5:305-341.

AZEVEDO, A.A. \& LINARDI, P.M. 2002. Streblidae (Diptera) of Phyllostomidae bats from Minas Gerais, Brazil. Mem. Inst. Oswaldo Cruz 97:421-422. PMid:12048576. http://dx.doi.org/10.1590/S007402762002000300026

BERTOLA, P.B., AIRES, C.C., FAVORITO, S.E., GRACIOLli, G., AMAKU, M. \& PINTO-DA-ROCHA, R. 2005. Bat flies (Diptera: Streblidae, Nycteribiidae) parasitic on bats (Mammalia: Chiroptera) at Parque Estadual da Cantareira, São Paulo, Brazil: parasitism rates and host-parasite associations. Mem. Inst. Oswaldo Cruz. 100:25-32. PMid:15867959. http://dx.doi.org/10.1590/S0074-02762005000100005

COIMBRA JUNIOR, C.E.A., GUIMARÃES, L.R. \& MELLO, D.A. 1984. Ocorrência de Streblidae (Diptera: Pupipara) em morcegos capturados em regiões de cerrado do Brasil Central. Rev. Bras. de Entomol. 28(4):547550.

DIAS, P.A., SANTOS, C.L.C., RODRIGUES, F.S., ROSA, L.C., LOBATO, K.S. \& REBÊLO, J.M.M. 2009. Espécies de moscas ectoparasitas (Diptera, Hippoboscoidea) de morcegos (Mammalia, Chiroptera) no estado do Maranhão. Rev. Bras. Entomol. 53(1):128-133. http://dx.doi. org/10.1590/S0085-56262009000100027

DICK, C.W. \& GRACIOLLI, G. 2008. Checklist of world Streblidae (Diptera: Hippoboscoidea). http://fm1.fieldmuseum.org/aa/Files/cdick/Streblidae Checklist_18sep08.pdf (último acesso em 06/05/2009).

GARDNER, A.L. 2007. Mammals of South America: Marsupials, Xenarthrans, Shrews, and Bats. University of Chicago, Chicago, Londres, v.1.

GRACIOLLI, G. \& CARVALHO, C.J.B. 2001. Moscas ectoparasitas (Diptera, Hippoboscoidea, Nycteribiidae) de morcegos (Mammalia, Chiroptera) do Estado do Paraná, Brasil. I. Basilia, taxonomia e chave pictórica para as espécies. Rev. Bras. Zool. 18(3):33-49. http://dx.doi.org/10.1590/ S0101-81752001000500002

GRACIOLLI, G. \& RUI, A.M. 2001. Streblidae (Diptera, Hippoboscoidea) em morcegos (Chiroptera, Phyllostomidae) no nordeste do Rio Grande do Sul, Brasil. Iheringia. Sér. Zool. 90:85-92.

GRACIOLLI, G. \& BERNARD, E. 2002. Novos registros de moscas ectoparasitas (Diptera, Streblidae e Nycteribiidae) em morcegos (Mammalia, Chiroptera) do Amazonas e Pará, Brasil. Rev. Bras. Zool. 19(Supl. 1):77-86.

GRACIOLLI, G. \& LINARDI, P.M. 2002. Some Streblidae and Nycteribiidae (Diptera: Hippoboscoidea) from Maracá Island, Roraima, Brazil. Mem. Inst. Oswaldo Cruz. 97(1):139-141. PMid:11992166. http://dx.doi. org/10.1590/S0074-02762002000100026

GRACIOLLI, G. \& AGUIAR, L.S. 2002. Ocorrência de moscas ectoparasitas (Diptera, Streblidae e Nycteribiidae) de morcegos (Mammalia, Chiroptera) no Cerrado de Brasília, Distrito Federal, Brasil. Rev. Bras. Zool. 19:177-181. http://dx.doi.org/10.1590/S0101-81752002000500012

GRACIOLLI, G., AZEVEDO, A.A., ÁRZUA, M., BARROS-BATTESTI, D.M. \& LINARDI, P.M. 2008. Artrópodos ectoparasitos de morcegos no Brasil. In Morcegos no Brasil: Biologia, Sistemática, Ecologia e Conservação (S.M. Pacheco, R.V. Marques, \& C.E.L Esbérard, eds.). Armazém Digital, Porto Alegre, p.123-138.

GUERRERO, R. 1994. Catalogo de los Streblidae (Diptera: Pupipara) parasitos de murciélagos (Mammalia: Chiroptera) del Nuevo Mundo. IV. Trichobiinae com alas desarrolladas. Bol. Entomol. Venez., Nueva Serie. 9(2):161-192.

GUERRERO, R. 1995a. Catalogo de los Streblidae (Diptera: Pupipara) parasitos de murciélagos (Mammalia: Chiroptera) del Nuevo Mundo. III. Los grupos: dugesii, dunni y phyllostomae del genero Trichobius Gervais, 1844. Acta Biol. Venez. 15(3-4):1-27. 
GUERRERO, R. 1995b. Catalogo de los Streblidae (Diptera: Pupipara) parasitos de murciélagos (Mammalia: Chiroptera) del Nuevo Mundo. V. Trichobiinae com alas reducidas o ausentes y micielaneos. Bol. Entomol. Venez. Nueva Serie 10(2):135-160.

GUERRERO, R. 1996. Catalogo de los Streblidae (Diptera: Pupipara) parasitos de murciélagos (Mammalia: Chiroptera) del Nuevo Mundo. VI. Streblinae. Acta Biol. Venez. 16(2):1-25.

GUERRERO, R. 1997. Catálogo de los Streblidae (Diptera: Pupipara) para sitos de murciélagos (Mammalia: Chiroptera) del Nuevo Mundo. VII. Lista de especies, hospedadores y paises. Acta Biol. Venez. 17:9-24.

GUIMARÃES, L.R. 1938. Sobre as espécies sul americanas do gênero Trichobius (Diptera-Streblidae). Rev. do Museu Paulista. 23:651-666.

KOMENO, C.A. \& LINHARES, A.X. 1999. Bat flies parasitic some phyllostomid bats in Southeastern Brazil: parasitism rates and hostparasite relationships. Mem. Inst. Oswaldo Cruz 94:151-156. PMid:10224519. http://dx.doi.org/10.1590/S0074-02761999000200004
PREVEDELlO, J.A., GRACIOLLI, G. \& CARVALHO, C.J.B. 2005. A Fauna de dípteros (Streblidae e Nycteribiidae) ectoparasitos de morcegos (Chiroptera) do Estado do Paraná, Brasil: composição, distribuição e áreas prioritárias para novos estudos. Biociências. 13(2):193-209.

RIOS, G.F.P., SÁ-NETO, R.J. \& GRACIOLLI, G. 2008. Fauna de dípteros parasitas de morcegos em uma área de Caatinga do nordeste do Brasil. Chirop. Neotrop. 14(1):339-345.

VIZOTTO, L.D. \& TADDEI, V.A. 1973. Chave para a determinação de quirópteros brasileiros. Ver. Fac. Filos. Ciênc. Letras Bol. Ciênc. São José do Rio Preto 1:1-72.

WENZEL, R.L. TIPTON, V.J. KIEWLICZ A. 1966. The streblid batflies of Panama (Diptera: Calyptera: Streblidae). In Ectoparasites of Panama (R.L. Wenzel \& V.J. Tipton, eds.). Field Museum Natural History, p.405-675.

WENZEL, R.L. 1976. The streblid batflies of Venezuela (Diptera: Streblidae). Brigham Young Univ. Sci. bull. Biol. Ser. 20(4):1-177.

WHITAKER JUNIOR, J.O. \& MUMFORD, R.E. 1977. Records of ectoparasites from Brazilian mammals. Entomol. News 88:255-258.

Received 06/18/2012

Revised 05/21/2013

Accepted 06/17/2013 